\title{
CLAVIUS, PROCLUS, AND THE LIMITS OF INTERPRETATION: SNAPSHOT-IDEALIZATION VERSUS PROJECTIONISM
}

\author{
Guy Claessens \\ Catholic University of Leuven
}

It is hard to overestimate the role played by Christopher Clavius (1538-1612), professor of mathematics at the Collegio Romano from 1565 until his death, in the establishment of mathematics as an incontestable part of the Jesuit curriculum and body of thought. ${ }^{1}$ Besides his direct influence on the constitution of the mathematical part(s) of the Ratio studiorum, ${ }^{2}$ Clavius's mathematical writings, ranging from introductory textbooks to commentaries to polemical pamphlets, ${ }^{3}$ almost immediately began to serve as standard references, despite their - occasionally - controversial character. Today, Clavius's contentious stand towards the older school at the Collegio embodied in the person of Benedictus Pereira, who held an extremely negative view on mathematics, is regarded as a decisive factor in the sixteenth-century renaissance of mathematics, both within and outside the Society. ${ }^{4}$

Nowadays, most scholars ${ }^{5}$ seem to agree that the philosophical framework of Clavius's institutional struggle can be found in the Prolegomena to his edition of Euclid's Elements, first published in Rome in 1574. According to some, ${ }^{6}$ the general outlines of this preface reflect a philosophy of mathematics that is largely indebted to the one presented by the Neoplatonist Proclus (410/412 - 485) in the double prologue of his commentary on the first book of Euclid's Elements. Without wanting to obscure the importance of Clavius's revolutionary project, I will try to sketch a different picture of Clavius's philosophy of mathematics, both on the ontological and on the epistemological level. In this re-evaluation, the limits of both Proclus's influence and the interpretation of his commentary on Euclid will be my primary focus.

Clavius's views on the nature of mathematical objects will be shown to be incompatible with the two conventional modes of interpretation found in the ancient commentators, namely the projectionism maintained by Proclus on the one hand, and the constructive abstractionism of writers such as Ammonius and Philoponus on the other. For Proclus, mathematical objects are extended and divisible projections of the unextended and indivisible ideas with which our understanding is equipped. The imagination acts both as the faculty that projects these ideas and as the imaginary screen on which they are projected. The constructive abstractionism read in Ammonius, for example, sees mathematical entities as existing only in the mind of the mathematician who in thought has separated, i.e. abstracted, them from matter.

Clavius's position will lay bare the need to invoke a third category, namely that of a 'snapshot-idealization': in mathematics, according to Clavius, sensible objects are indeed considered free from matter, but they are not attributed any properties that they do not perfectly instantiate as sensible objects. As in a photograph, certain 
features, for example matter and space, are not taken into consideration, but this does not mean that other, in particular mathematical, aspects are misrepresented or abstracted into another ontological level.

The philosophy of mathematics developed by Clavius not only proves to be an original and ingenious answer to the questions raised by the sixteenth-century Quaestio de certitudine mathematicarum, where Proclus appears as a main authority, but at the same time furnishes Jesuit mathematicians with a meta-mathematically guaranteed raison d'être on the institutional level, vis-à-vis their colleagues in natural philosophy. Although Clavius's institutional merits are widely recognized in current research, the philosophical underpinnings of that struggle have not yet been studied in depth, and are mostly held as merely copying Proclus's thoughts and therefore lacking any originality.

\section{LITERARY AND INTELLECTUAL BACKGROUND}

First of all, the meaning and scope of the Prolegomena can be fully grasped only by placing it against the broader intellectual background in which it appeared. If, at first glance, the Prolegomena seem to be a mere introduction to Euclid's Elements, a closer look at both its literary and intellectual contexts shows that there is much more at stake. Despite its concise nature, Clavius's preface fulfilled a role similar to that of other prefaces of the same period.

These paratexts were also read in a manner that exceeded their introductory function, so that they served as quasi-independent, meta-mathematical reflections. ${ }^{7}$ Thus, due to this broader application, Clavius's introduction was not limited to the demands of a conventional prologue and had the opportunity to tackle questions raised by the intellectual climate of its day. After all, ever since the appearance of Alessandro Piccolomini's treatise Commentarium de certitudine mathematicarum, published in Rome in 1547 as an appendix to his paraphrase of the pseudo-Aristotelian Quaestiones mechanicae, the scientific value of mathematics had been severely on the defensive. Yet Piccolomini's attack on mathematics did not so much intend to question the certainty of mathematics, but rather to invalidate the arguments traditionally appealed to in order to ground that certainty. To that end, a fundamental shift from the logical to the ontological realm was brought about by the Siennese philosopher.

Piccolomini's quarrel with tradition, and the debate it was about to provoke, are exemplary of the transformation occurring in the (re-)reading of Aristotle during the sixteenth century. ${ }^{8}$ The recovery, translation, and publication of the Greek commentators (such as Ammonius, Philoponus, Themistius, and Simplicius) provided a privileged access to Aristotle that had previously been unavailable. Of crucial importance is the fact that the Greek commentators did not simply transmit Aristotle's theories. By also mentioning rival ones, they embodied a new, 'critical' reading of Aristotle. ${ }^{9}$

A further boost (certainly in the field of meta-mathematics) was given by the publication of Proclus's Commentary on the First Book of Euclid's Elements in 1533 by Simon Grynaeus. This work also played an important role in more technical 
discussions among mathematicians such as the one on the angulus contactus. ${ }^{10}$

Piccolomini explicitly names Proclus as the supportive authority he needed to risk revealing his controversial opinion ${ }^{11}$ and both Piccolomini's supporters and adversaries refer to Proclus as an argumentum auctoritatis. ${ }^{12}$ It is indeed very unlikely that Proclus was simply put forward by Piccolomini among "wonderful authorities", ${ }^{13}$ without there being any general acceptance of the validity of the claim that Proclus actually was an authority. But what were the possible reasons for the Neoplatonist to be acknowledged as an authority in the field of mathematics at that time? First of all, one may assume that Proclus, as the author of a Greek commentary on Euclid, shared in the high esteem acquired by the ancient commentators in general. Both in language and in thought, they were considered to be 'closer', and therefore more truthful, to ancient philosophy than medieval commentaries based on Latin translations. ${ }^{14}$ Secondly, Proclus simply proved to be, I think, a 'useful' authority, i.e. 'the right man at the right time'. He dealt with the subject of mathematical demonstration from a philosophical standpoint and cleverly integrated an Aristotelian theory of demonstration within a generally Platonic philosophical framework. ${ }^{15}$

Proclus thus met the Renaissance mathematicians' needs in two crucial ways. Firstly, he furnished them with 'ancient' arguments — both utilitarian and philosophical - for a defence and reappraisal of mathematics from a meta-mathematical perspective. Secondly, although he was a Platonist, he left the door open for a syncretic and conciliatory approach ${ }^{16}$ by incorporating certain elements of Aristotle's philosophy.

Evidently, Piccolomini's reading of the Greek commentators and of Proclus's Commentary was not the only reason that lead to the publication of his controversial treatise. Its underlying purpose reflected a cultural and intellectual climate where the traditional boundary between mathematics and natural philosophy was apparently in need of a certain legitimation. It is the vivid interaction between the new material mentioned above and the growing invasion of mathematics into the territory of natural philosophy ${ }^{17}$ that endangered the monopoly of Aristotelian natural philosophy in dealing with nature. Therefore, both sides were forced to re-legitimize their respective positions.

\section{OPENING THE DEBATE: PICCOLOMINI'S QUARREL WITH TRADITION}

In the traditional view, held by Averroës and the Latin commentators, ${ }^{18}$ the mathematical sciences were considered to possess the highest degree of certainty, since they make use of so-called demonstrationes potissimae, a technical term indicating the type of demonstration that gives knowledge of both the fact (quia) and the true and immediate cause (propter quid) of that fact. ${ }^{19}$ This opinion was challenged by Piccolomini. He argues that mathematical demonstrations are unable to live up to the (or at least Piccolomini's) strict demands of a demonstratio potissima. Their major premises do not have the form of a definition and their middle terms are not always the unique and proximate cause of the property proved. ${ }^{20}$

But, as we have seen, for Piccolomini this 'failure' of mathematical demonstrations 
as potissimae does not undermine the certainty of mathematics. On the contrary, this certainty only has to be looked for (and found) elsewhere, namely in the abstract nature of mathematical objects:

So Proclus concludes from Plato that the mathematical entities, about which demonstrations are made, are neither fully sensibles in the subject, nor entirely freed from it [i.e. the subject], but that those mathematical figures are found in the phantasia, the occasion being afforded by the quantities found in sensible matter.... Thus, the matter of these sciences will be, so to say, in this way imagined quantity.... ${ }^{21}$

The ontological status ascribed to mathematical objects by Piccolomini is as follows: they exist only in the phantasia as abstractions, the occasion being afforded by the most generally shared sensible accident, ${ }^{22}$ the quantities found in sensible objects. These quantities are nothing but the most common accidental properties of perceptibles and the easiest to abstract.

Here, Piccolomini adopts Averroës's conception of quantity as the most general sensible accident: the matter of mathematics, i.e. 'imagined' quantity (quantum phantasiatum), is the undetermined quantity that inheres in primary matter before it is embodied in a substantial form, ${ }^{23}$ or, in other words, the possibility of acquiring spatial determinations. ${ }^{24}$ Since in reality matter and form are always entangled, the matter of mathematics can only be imagined (phantasiatum). After all, being thought in relation to a subject, undetermined quantity can no longer be considered as undetermined, and will always be 'filled in', i.e. will have received an extension determined by a specific form and thus subject to change. This is also the reason why, claims Piccolomini, among natural quantities no full equality exists, nor are perfect triangles or circles found. ${ }^{25}$ However, since quantity, as the most common accident, does not depend on any specific substance, it is the easiest to abstract; an abstraction moreover (in plain terms) into a perfect, ideal environment, where lines have no width and points are indivisible.

By means of this ontology, the goal of Piccolomini's Commentarium is brought to light. Concerned only with the non-essential quantitative characteristics of perceptible objects, abstracted into an imagined, undetermined quantity, mathematics can now be radically opposed and made inferior to physics, in which the true nature of things, expressed by means of the Aristotelian causes, is understood. ${ }^{26}$ Thus, the certainty of mathematics is guaranteed, but, in a way - at least for comprehending the true nature of sensible objects - it is also made redundant and useless. Piccolomini's simplification $^{27}$ of the objects of mathematics installs an unbridgeable ontological gap between mathematical and sensible objects on the one hand, and an epistemological fissure between mathematics and physics on the other. Moreover, by transposing the certainty of mathematics from the logical to the ontological level, Piccolomini wittingly or unwittingly made the ontological status of mathematical objects what would be crucially at stake in the forthcoming debate.

Piccolomini ascribes the above-mentioned view to Proclus ("concludit ergo Proclus 
ex Platone"). For a correct assessment of this claim, a brief sketch of Proclus's philosophy of mathematics is indispensable. ${ }^{28}$ According to Proclus, mathematical objects occupy an intermediary position between the objects of intellect and the objects of sense-perception. ${ }^{29}$ This place in between is the consequence of their "Janus head" relation to both realms: they are inferior to the former in so far as they are divisible, they surpass the latter because they are more simple and devoid of matter. The "epistemic correlates" ${ }^{30}$ are the following: the higher Forms are apprehended in a non-discursive, fully-grasping way by the faculty called $v o \tilde{v} \varsigma$, the lower sensible objects are the object of mere opinion ( $\left.\delta \delta^{\xi} \alpha\right)$, and, finally, the intermediate mathematical objects are dealt with in a discursive way, using imaginative representations $(\pi \rho \circ \beta \circ \lambda \alpha \imath)$ of the $\lambda o ́ \gamma o \iota$. The corresponding faculty here is understanding $(\delta \iota \alpha \dot{v o \iota} \alpha)$.

This last process of 'projectionism' forms the core of Proclus's philosophy of mathematics. Due to and within the imagination $(\phi \alpha v \tau \alpha \sigma i \alpha)$, the unextended and indivisible ideas $(\lambda o ́ \gamma o \iota)$ with which the understanding is equipped are projected ( $\pi \rho \circ \beta \alpha \dot{\alpha} \lambda \varepsilon \tau \alpha \iota)$ as extended and divisible, thereby making them into possible objects of discursive reasoning, i.e. mathematical objects.

Because of this intermediary state, through mathematical objects, one is able to 'bridge' the gap between both intelligible and sensible objects. In an upward movement, they bring us into contact with the intelligible world itself: in a downward movement, they serve as paradigmatic references for the perceptibles. Nevertheless, it is beyond doubt that for Proclus, the destination of mathematics mainly lies in the upward journey. ${ }^{31}$

It is highly remarkable that, in his reading of Proclus, Piccolomini simply ignored or misinterpreted the omnipresent projectionist point of view, especially considering the latter's fierce attack on the abstractionism-thesis. ${ }^{32}$ In the main, says Proclus, two opposite views on the being of mathematical objects have been held. ${ }^{33}$ On the one hand, there is the opinion that they are derived from sensible objects, either by abstraction or by collection from particulars. On the other hand, there is Plato's claim that they should have an existence prior to sensible objects.

In what follows, Proclus demonstrates the correctness of the Platonic view, by raising three fundamental objections against the 'derivation-from-sensibles thesis'. These are, given the numerous puns, ${ }^{34}$ clearly aimed at Aristotle. Firstly, if mathematical objects are derived from sensible ones, where does their exactness and stability come from? Evidently, their precision springs from the soul, which is therefore the generatrix of mathematical objects. ${ }^{35}$ Secondly, if our mathematical ideas are inferred from perceptibles, should we then not use terms from the sense world in our demonstrations, since the premises must be of the same family as the demonstrations? Obviously, this would conflict with the assertion that a universal premise is better for demonstration than a particular, and that demonstrations from universals are more truly demonstrative. ${ }^{36}$ Thirdly, if the soul fabricates in herself secondary images of the more truly existent things that matter receives from nature, would this not make the soul less honourable than matter? Such a statement is (according to the Neoplatonist) clearly nonsense, since the soul is the place of primary and matter 
of secondary realities. ${ }^{37}$ On the whole, Proclus's objections are all variations of a broader presupposition that what is more universal is ontologically prior to what is less universal. ${ }^{38}$

At first glance, there are two possible 'excuses' for Piccolomini's abstractionist interpretation of Proclus. ${ }^{39}$ (However, these by no means weaken the assertion that his reading is incorrect or, at least, imprecise.) Firstly, since the abstractionist thesis was widespread among other ancient commentators, ${ }^{40}$ it is possible that Piccolomini thought he could simply assimilate Proclus within this general tendency. Secondly, some of Proclus's expressions may, if considered apart from the context in which they appear, give rise to an abstractionist interpretation. ${ }^{41}$ Yet the fact that Piccolomini remains silent about Proclus's attack on abstractionism, strengthens the thesis of a wantonly false reading, rather than that of an unfortunate misinterpretation. In that case, I believe, the above 'excuses' were convenient for Piccolomini rather than misleading.

As Anna De Pace rightly notices,${ }^{42}$ the only two 'genuine' Proclean elements adopted by Piccolomini are the following: the adaptation of the phantasia as the necessary faculty for 'doing' geometry, and the intermediary position of this faculty. The rest of Piccolomini's theory can grosso modo be labelled 'Aristotelian', with the caveat that such labels are insufficient for the eclectic positions taken during the sixteenth century.

\section{TAKING UP THE CHALLENGE: BAROZZI'S RESPONSE TO PICCOLOMINI}

Piccolomini's attack did not go unnoticed. In 1560 Francesco Barozzi, professor of mathematics at Padua and author of the first Latin translation of Proclus's Commentary, ${ }^{43}$ was the first one to take up Piccolomini's challenge with the publication of his Opusculum, in quo una oratio, et duae quaestiones: altera de certitudine, et altera de medietate mathematicarum, continentur. The title clearly betrays the intention to offer a direct answer to Piccolomini's arguments.

As Maarten van Dyck claims, ${ }^{44}$ Barozzi's answer consists in fact of an ingenious - and in a certain way even witty - twist on Piccolomini's arguments. The latter had, after all, implicitly accepted the intermediary position of mathematical objects, though only for hammering away at the imperfection of mathematics, which followed from the separation of its objects from natural objects. From Barozzi's perspective, this separation from perceptibles becomes an argument precisely for the higher degree of perfection reached in mathematical objects. In other words, by reintroducing the idea of medietas in a Platonic scheme (where it belonged), the objects of mathematics are again lifted above the changing and corruptible nature of the sensible realm ${ }^{45}$ and directed towards the 'true' nature of reality, i.e. the intelligible world. Finally, by applying Piccolomini's own claim that there has to be some correspondence between the objects of a science and the demonstrations used, Barozzi contends that the greater certainty of the mathematical objects is necessarily reflected in mathematical demonstrations, which thereby outdo the demonstrations appealed to in physics. 
During the following decades, the debate originating with Piccolomini remained a 'hot topic' in mathematical-philosophical circles. It was nourished by the contributions of - among others - Pietro Catena, Barozzi's successor at the University of Padua, who attacked the idea of abstractionism, and the Jesuit natural philosopher Benedictus Pereira, who advocated Piccolomini's case from the Collegio Romano. It is in this polemical context, generally referred to as the Quaestio de certitudine mathematicarum, that Clavius's Prolegomena were published. And, considering our remarks on the wider scope of the preface, it is hardly surprising that Clavius's text displays distinct echoes of this discussion. ${ }^{46}$

\section{CLAVIUS AND BAROZZI'S PHILOSOPHY OF MATHEMATICS}

The 'philosophy of mathematics' adhered to by Clavius for taking sides in the Quaestio, has generally been labelled Proclean by present-day scholars. ${ }^{47}$ It is indeed beyond a doubt that Clavius was acquainted with Proclus's Commentary on the First Book of Euclid's Elements - particularly with Barozzi's Latin translation of 1560, which he explicitly mentions. ${ }^{48}$ Moreover, in the passage from the Prolegomena commonly referred to as evidence for Clavius's supposedly Proclean view, Proclus is invoked as an argumentum auctoritatis: 49 "ut recte a Proclo probatur". However, it goes without saying that neither Clavius's acquaintance with Proclus's text, nor his appeal to the latter as an authority, imply that Clavius simply — let alone correctly - adopted Proclus's point of view. Piccolomini, for example, explicitly called upon the Neoplatonist for support, yet he misread him as a defender of an abstractionist theory. So, what is it that according to some is so Proclean about Clavius's ideas? The key passage seems to be the following one:

Since the mathematical disciplines deal with things that are considered apart from any sensible matter, although they are really immersed in matter, it is clear that they occupy a place intermediate between metaphysics and natural philosophy. For, if we consider the subject matter of these, as is rightly shown by Proclus, the subject matter of metaphysics is separated from all matter, both in reality and in reason; that of physics, on the contrary, is connected to sensible matter both in reality and in reason. Hence, since the subject of the mathematical disciplines is considered apart from any matter, although it is really found in it, it is an established fact that it holds an intermediate position between the other two. Yet if the nobility and excellence of a science has to be judged by the certainty of the demonstrations it uses, undoubtedly the mathematical disciplines will hold the first place among all others. ${ }^{50}$

First of all, by advancing this hierarchical structure of the sciences, Clavius incorporates, and at the same time secures, mathematics as an indispensable part of philosophy, on an equal footing with both natural philosophy and metaphysics. ${ }^{51}$ Without a doubt, this assertion has to be understood as a direct response to those who denied (Aristotelian) scientific value to mathematics, such as Piccolomini and Pereira. ${ }^{52}$ Furthermore, Clavius's reply obviously not only offers a defence of mathematics, but 
also a cunning attack on the unchallenged position of natural philosophy, similar to Barozzi's. Regarding the certainty of the demonstrations used, mathematics in this scheme exceeds both natural philosophy and metaphysics. Since the mathematical disciplines demonstrate their claims on the most solid grounds, they are, as it were, beyond all doubt. That this is not the case for other sciences is apparent, according to Clavius, from the multitude of opinions existing in those fields, such as the existence of numerous schools of Peripatetics, who disagree "as the various branches of a common trunk". 53

The combination of mathematics' epistemological intermediacy and pre-eminence enables Clavius to assign to mathematics the key role in the whole of speculative philosophy. In the chapter "Various uses of the mathematical disciplines", the above scheme is reiterated, with an explicit reference to Proclus, by introducing mathematics as a bridge between natural philosophy and metaphysics. ${ }^{54}$

The ontology and epistemology upon which Clavius founds his restoration and reappraisal of mathematics are, as mentioned above, invigorated by the authority of Proclus. At first glance, one aspect indeed seems to be genuinely Proclean: the intermediary position of the mathematical objects, and the intermediateness of the mathematical sciences resulting from it. According to Chikara Sasaki, Clavius here sides with Proclus by repeating Barozzi's epistemology "which is fundamentally eclectic but influenced most by Proclus": ${ }^{55}$

As seen from our perspective, natural science comes first, mathematics second, and divine science third: in the order of nature, on the other hand, divine science is first, mathematics second, natural science last, so that mathematics always is truly in the middle between natural science and divine science.... ${ }^{56}$

The epistemology presented here by Barozzi consists in a reconciliation between Plato and Aristotle stemming from Ammonius. ${ }^{57}$ At first glance, Barozzi says ${ }^{58}$ Plato, who prefers mathematics to natural philosophy, and Aristotle, who puts natural philosophy prior to mathematics, seem to disagree. However, by subtly introducing the "from our perspective [quoad nos]" and "in the order of nature [quoad naturam]" qualifiers, the contradiction vanishes. Now Barozzi is able to show that it is only a matter of different, but in the end complementary, perspectives, both of which grant mathematics its rightful place in the middle.

The claim however, that Clavius's ranking of the sciences forms a rather uninspired copy of Barozzi's assertion, ${ }^{59}$ is somewhat derogatory to our Jesuit mathematician's genius. Where the epistemology, i.e. the tripartite division of the speculative sciences and mathematics' intermediary position, indeed remains unaltered by Clavius, the ontology that functions as its starting-point is quite different. If we have a look at Barozzi's Oratio ad philosophiam virtutemque ipsam adhortatoria, delivered in Padua in $1557,{ }^{60}$ we find the broad outlines of an ontology corresponding with and sustaining the epistemology mentioned above:

Some things are fully immersed in matter, so that neither according to [their] being nor according to reason can they be separated from matter: these are called 
natural objects. Others are, both according to [their] being and according to [their] proper consideration, separated from matter, and these we call divine objects. Still others, which can indeed be separated from sensible matter according to [their] proper consideration, but not at all according to [their] being, are termed mathematical objects. ${ }^{61}$

Combined with Barozzi's following statement, one is tempted to read this ontology as very akin to Piccolomini's:

Yet, one has to realize that, as long as mathematical objects exist in sensible matter, they are said to be natural objects; but when they have been separated from any sensible matter, then they are truly called mathematical essences, which do not exist anywhere but in the phantasia and in our soul. ${ }^{62}$

To both, the mathematical objects exist only in the phantasia - an idea derived from Proclus - as a result of a rational separation from sensible matter; the only difference being that for the former this separation is a benefit, for the latter, a great loss. In short, the disparity between Barozzi and Piccolomini then comes down to looking at the same ontology through either Platonist or Aristotelian spectacles - an ontology that, moreover, can barely be called Proclean, since the process of constructing mathematical objects, i.e. by abstraction/separation, depends on and starts with objects found in the sensible realm, and does not involve any kind of projectionism or innatism, according to which the mind is fitted out with innate or inborn ideas that are not derived from sense experience.

However, falling back on the above-cited artificial and selective collation of ideas in order to reconstruct the ontology maintained by the Paduan professor, seems to some extent problematic. After all, as De Pace asks, ${ }^{63}$ how could one reconcile the just-mentioned ontological framework with Barozzi's next utterance, also found in his Lectiones in Procli commentarios:

But other things (as our Proclus here and there affirms, and as will be more clear to us in what follows) are both according to [their] being and according to [their] proper consideration separated from sensible matter and exist in intelligible matter: those are called mathematical objects and they are considered by the mathematical part of contemplative philosophy. ${ }^{64}$

Here, Barozzi appears to take Proclus's side by introducing the notion of intelligible matter and excluding the possibility of abstractionism, since the mathematical objects are also according to their being (secundum esse) separated from sensible matter.

Given the contradictory testimonies quoted above, it is not a settled question whether Barozzi is inclined to embrace an abstractionist point of view or not. However, De Pace's reference to Barozzi's letter to Alvise Buonrizzo, ${ }^{65}$ in which the former claims to believe in the possibility of a successful reconciliation between the Platonic innatism doctrine and Aristotle's theory of abstraction, may indeed function as a stimulus to rethink and reformulate our question. Perhaps for Barozzi, the contradictions we observe were not contradictory at all. ${ }^{66}$ This argument is, however, 
not entirely convincing, since Barozzi does not mention the specific (ontological) status of mathematical objects in his letter to Buonrizzo, and confines himself only to innatism and abstractionism in general. After all, the contradiction here is not that between Platonic Ideas and Aristotelian Universals, but that between abstract and 'projected' mathematical entities.

Yet I think there is a way of making the apparent contradiction more understandable. If we consider Barozzi's mathematical philosophy to be fundamentally 'abstractionist', while noting that, from his broader Platonic perspective, this process of separation equalled an ontological gain (as discussed above), it is not unlikely that his reading of Proclus would show traces of this abstractionist view.

As we have seen, Barozzi adopted Proclus's medietas-idea for consolidating mathematics' supremacy over natural philosophy, and took up the role assigned to both the phantasia and the notion of intelligible matter; three aspects that nevertheless do not undermine an overall abstractionist view. Moreover, it is quite remarkable that even in his Lectiones in Procli commentarios, a clearly abstractionist tone is heard. As long as mathematical objects exist in sensible matter, they are natural objects, but once separated, they are truly mathematical objects. In my opinion, Barozzi is able to establish a partial reconciliation by broadening the meaning of "secundum esse": qua mathematical objects, mathematical objects exist only in the phantasia and in the soul, i.e. in intelligible matter ("nullibi nisi in phantasia et in anima nostra subsistunt"), and are thus separated from sensible matter ("cum secundum esse ... a materia sensibili separata sunt"). One could call this kind of being a "derivative being", or at least "being" in a very loose sense, where the relation between ratio essendi and ratio cognoscendi is not totally clear. On the other hand, before the act of separation, they exist in sensible matter ("dum in materia sensibili haec consistunt"), but not yet qua mathematical objects ("res naturales esse dicuntur").

In this interpretation, the primary existence of mathematical objects lies in sensible matter, but once separated (by thought), they also have a derivative being in the phantasia, so that if one would ask the question "What is the being of mathematical objects?", the answer would depend on the point of view chosen. In this way, Barozzi is able to say that mathematical objects are both separated from sensible matter (according to their derivative being) and inseparable from sensible matter (according to their primary being). Obviously, this hypothesis is nothing but one way to present a coherent reading of Barozzi's text, and remains open to nuances, corrections and further additions. Finally, this would also mean that Barozzi's philosophy of mathematics is, despite a generally Platonic approach, essentially 'un-Proclean'.

\section{CLAVIUS'S PHILOSOPHY OF MATHEMATICS: SNAPSHOT-IDEALIZATION}

When we have a look at Clavius's Prolegomena, the ideas of Proclus seem even further away. According to our Jesuit mathematician, the subject matter of mathematics is found (reperiatur) in sensible matter, ${ }^{67}$ but is nevertheless considered free from it ("absque ulla materia sensibili considerantur" and "extra omnem materiam consideretur"). 
Mathematical entities are thus, in a way, both abstract and immersed in matter. ${ }^{68}$ At first glance, the ontology portrayed by Clavius plainly differs from Barozzi's. The ontological gap established by the Paduan professor between sensible objects and mathematical entities — the latter only existing as such in the phantasia ("nullibi nisi in phantasia et in anima nostra subsistunt"), has been closed, and only the manner in which both are considered indicates the difference.

This classification of subject matter (and the corresponding sciences), stemming from Aristotle, ${ }^{69}$ was frequently used in the Latin West from the early Middle Ages. ${ }^{70}$ Yet Clavius's originality lies in the fact that his reading of this conventional taxonomy is at odds with the two general modes of interpretation maintained by Aristotle's commentators, i.e. projectionism ${ }^{71}$ and constructive abstractionism. ${ }^{72}$ The latter view, namely that mathematical objects exist only in the mind of the mathematician who reasons about triangles, angles, etc., which he conceives separately from matter, was developed by pseudo-Alexander and accepted by Porphyry, Ammonius, and Philoponus. ${ }^{73}$

One could argue that, in the end, there is no significant difference between Clavius's approach and the constructive abstractionism adhered to by Porphyry, Ammonius, and Philoponus. After all, in both cases, sensible matter is left out of consideration or 'abstracted away from', and what one is left with, i.e. a mathematical object, seems to be identical. The only contrast is that, for Clavius, mathematical objects here remain at the same ontological level as sensible ones, and that, for the above commentators, they are conceived of as mental constructions based on sensible perception. From this perspective, the being present or absent of an ontological breach may seem somewhat accessory, but if one takes a closer look at Pereira's claims, to which the Prolegomena are a direct response, it appears to be more than just a negligible variation on the same theme.

Adopting and elaborating upon Piccolomini's conception of quantity, i.e. quantity as co-existent with prime matter, and hereby prior to or independent of any actualization by the spatial determinations that the substantial form brings to prime matter, Pereira, in his De communibus omnium rerum naturalium principiis (1576), radically opposes quantity as mathematical and abstract extension to quantity as physical extension. The subject matter of mathematics is not the particular physical extension of a sensible object, but rather abstract quantity. This distinction is elucidated by the example of a sphere that touches a plane at a single point: this is indeed true for a sphere as an abstract and mathematical quantity, but false for a sphere as a physical, extended thing. ${ }^{74}$ Obviously, both for Piccolomini and Pereira, the ontological gap they establish turns out to be unbridgeable: sensible objects do not perfectly instantiate the properties of abstract mathematical objects.

In my opinion, Clavius is capable of countering this issue by means of his wellconsidered formulation of the subject matter of the mathematical disciplines: “... disciplinae mathematicae de rebus agunt, quae absque ulla materia sensibili considerantur, quamvis reipsa materiae sint immersae", and "subiectum mathematicarum disciplinarum extra omnem materiam consideretur, quamvis re ipsa in ea reperiatur". Here, 
I think, a parallel with Aristotle's Metaphysics M3, 1077b24-30 can be drawn:

There are many statements about things merely considered as items in motion, independently of what each such thing is and apart from their accidents, and it is not therefore necessary that there is either something moving separately from perceptible objects or some separate entity in them. In the same way, in the case of items in motion, there will be statements and sciences which treat them not qua moving but only qua bodies, or again only qua planes, or only qua lines, or $q u a$ divisibles, or qua indivisibles having position, or only qua indivisibles. ${ }^{75}$

Aristotle here introduces a qua-operator that appears to function as some sort of predicate filter: ${ }^{76}$ perceptible objects, he says, can be considered only as moving - in isolation from all other particular predicates, and also only qua bodies, qua lengths, etc. Like the medical scientist who treats perceptible objects qua health, ${ }^{77}$ the mathematician studies sensible objects, but merely qua length, qua width, qua lines, and so on.

Applying a mathematical qua-operator, all predicates that concern the material composition of a specific object are 'filtered out', so that only the features that are relevant for mathematics remain. This outlook has two major implications. First of all, from this point of view, there is evidently no need for any ontological redoubling: mathematicians focus on one particular aspect of sensible objects, and therefore "the ontology that they presuppose does not require any substantial items other than these physical bodies". ${ }^{78}$ Secondly, the risk of idealization vanishes: mathematical objects exist to the degree that the mathematical properties considered are truly instantiated in the sensible objects studied. As a result, the only type of abstraction involved is the abstraction introduced by the qua locution. ${ }^{79}$

Moreover, this view does not undermine the idea of separation: by separating matter (i.e. the physical instantiation) from things immersed in matter, one does not necessarily create new mental types of objects. One only assumes the separated existence of things that in fact do not exist in separation from matter, ${ }^{80}$ that is, as some sort of 'working hypothesis'. ${ }^{81}$ The similarity with Clavius's “quamvis reipsa materiae sint immersae" is striking. As Aristotle says: "the best way of studying each thing would be this: to separate and posit what is not separate, as the arithmetician does and the geometer", ${ }^{82}$ a process appropriately described by Lear as a helpful fiction, rather than a harmful one, ${ }^{83}$ for "it makes no difference nor does any falsity result if they [sc. mathematical objects] are separated". ${ }^{84}$

It is of crucial importance to point out the specific meaning of the word 'abstraction' in this context, since, obviously, when Clavius talks about mathematical objects as "less abstract entities", ${ }^{85}$ he does not have in mind Piccolomini's "abstract quantities". For the former, abstraction is conceived of as — formulated negatively - filtering out the properties of sensible objects that are not mathematically relevant, i.e. 'make abstraction from' or 'leave unconsidered' the material composition of a specific object. For the latter, abstraction means to draw away the quantitative properties of sensible objects, and impose them on imagined matter. This last step is crucial, because from 
Piccolomini's point of view, the quantitative properties imposed on imagined matter are not the inexact properties of sensible objects precisely because they are imposed upon imagined matter. The fact that mathematical objects consist of imagined matter is the reason why mathematical entities, unlike perceptibles, can be perfect triangles, circles, etc., and can also be fully equal to each other.

Precisely by keeping silent about such notions as imagined or intelligible matter, Clavius precludes the possibility of any idealizing interference. The only idealization involved in the Jesuit's process of abstraction is a 'snapshot-idealization': by considering sensible objects free from matter, they are no longer subject to change but, on the other hand, they are not ascribed any properties that they do not perfectly instantiate as a sensible object. As in a photograph, certain aspects of reality are not taken into consideration, for instance matter and change, but this does not imply that other aspects, e.g. mathematical ones, are hereby misrepresented.

Thus, although Clavius's formulation is unable to address the heart of Piccolomini's critique, i.e. that mathematics deals merely with accidental properties, it does furnish mathematics with a right to speak when it comes to dealing with nature: first of all, since mathematical objects are perfectly instantiated in sensible objects, secondly, since the knowledge attained by mathematics is free from any doubt, and therefore truly scientific. ${ }^{86}$

Considering Barozzi's philosophy of mathematics, we could examine the question as to whether the abstraction adhered to by the Paduan professor substantially differs from Clavius's or not: that is, does the ontological gap also play a role here? After all, to both Clavius and Barozzi, mathematical objects are separated from matter, and this separation from matter appears to be the only idealization implied there.

Barozzi's conception of intelligible matter does not appear to imply the type of idealization that is coupled with Piccolomini's imagined matter. In fact, it seems to operate only as a counterweight to sensible matter, in so far as it is stable and not subject to change. In my opinion, the ontological gap established by the Paduan professor does not so much characterize a significant difference in both men's conception of mathematical entities, but rather illustrates the more refined and elaborated nature of Barozzi's philosophy of mathematics and the broader philosophical framework underlying it. Clavius, remaining silent on crucial elements such as phantasia and imagined/intelligible matter, leaves us with a rather poor epistemological and ontological framework upon which to build a coherent and articulate 'philosophy' of mathematics.

Accordingly, the parallel with the passage of Aristotle's Metaphysics I have drawn above merely serves as an elucidating and interpretative contextual frame and is not at all a call to identify Clavius's ideas on mathematics with Aristotle's. After all, that passage is only one relevant fragment of the complex whole (at least, if it can be considered a whole) of Aristotle's philosophy of mathematics, and its relation to other aspects is far from unproblematic, e.g. to Aristotle's tricky notion of intelligible matter. ${ }^{87}$

As Feldhay puts it, Clavius's real justification came from the practice of 
mathematics itself, ${ }^{88}$ i.e. its proven usefulness and educational value. Therefore, his reference to the authority of Proclus should be understood, I think, as a rhetorical way of engaging himself in the context of the Quaestio, rather than as a statement of philosophical interest. In Proclus, Clavius mainly found an ally for a utilitarian reappraisal of mathematics, not a philosophical one. ${ }^{89}$

\section{CONCLUSION}

From the foregoing, it is a matter of course that appealing to Proclus as an authority does not in itself warrant a 'correct' understanding or interpretation of the latter's ideas. Especially in the case of Clavius, where, from a strictly philosophical perspective, the range of his appeal to authority appears to be limited to a mere agreement on the intermediary position of mathematical entities, the elements upon which to found such a thesis are thin at best.

Even when confronted with an at first glance more thorough reading of Proclus's Commentary, e.g. in Piccolomini's and Barozzi's writings, a crucial aspect such as the Neoplatonist's projectionism-theory appears to be simply neglected or misinterpreted. Here 'Proclean' elements, such as the ontological intermediateness of the mathematical objects and the role of the phantasia as its epistemological correlate, prove to be handily incorporable into an abstractionist scheme. Yet both the fact that Clavius explicitly refers to Proclus and the latter's significance in the debate between Piccolomini and Barozzi give a clear indication of the influence and importance acquired by Proclus's Commentary in the early modern period.

The scarcity of 'building blocks' in Clavius's Prolegomena to reproduce an ontological and epistemological system (if, at least, such a thing has to be sought in the Jesuit's text) works both ways: referring to a fragment of Aristotle's Metaphysics as a starting point for a meaningful and coherent interpretation can only be a first step in the right direction. In my opinion, it is more appropriate to read the Prolegomena as a polemical dialogue with Piccolomini and Pereira, with the institutional struggle and its utilitarian approach in mind, rather than as the work of a Proclus-adept. The minimalist ontology and epistemology presented in the Prolegomena enabled Clavius both to counter Piccolomini's claims and to secure mathematics' key position in the Jesuit educational programme: mathematics gained a right to speak when it came to dealing with nature and, moreover, this right was legitimized by an epistemological certainty that was not to be found in natural philosophy nor in metaphysics. Mathematics was a true Aristotelian scientia and the institutionalization of a mathematical research program was hereby (again) legitimatized. Although Pereira's attempt to undermine mathematics' institutional identity within the Society was countered by Clavius, their quarrel illustrates the close connection between the epistemological position of mathematics and the socio-professional status of its practitioners..$^{90}$ 


\section{ACKNOWLEDGMENTS}

I would like sincerely to thank Amos Edelheit, Jan Papy, Steven Vanden Broecke, and Gerd van Riel for their helpful remarks following their reading of earlier versions of this article.

\section{REFERENCES}

1. A detailed biography can be found in Antonella Romano, La contre-réforme mathématique: Constitution et diffusion d'une culture mathématique jésuite à la Renaissance (Rome, 1999), 85-94, and in Dennis Smolarski, "The Jesuit Ratio Studiorum, Christopher Clavius, and the study of mathematical sciences in universities", Science in context, xxv (2002), 447-57, pp. 449-52.

2. Smolarski, op. cit. (ref. 1), 450.

3. For a detailed view of Clavius's literary production, see Eberhard Knobloch, "L'oeuvre de Clavius et ses sources scientifiques", in Luce Giard (ed.), Les jésuites à la Renaissance: Système éducatif et production du savoir (Paris, 1995), 263-83. Most of these works were re-edited in Christopher Clavius, Opera mathematica (Mainz, 1611-12), literally his opus magnum, published in five volumes, containing almost 4000 pages.

4. See Romano, op. cit. (ref. 1), 89.

5. For example, Peter Dear, Discipline and experience: The mathematical way in the scientific revolution (Chicago, 1995); Eckhard Kessler, "Clavius entre Proclus et Descartes", in Giard (ed.), op. cit. (ref. 3), 285-308; Rivka Feldhay, "The use and abuse of mathematical entities", in Peter Machamer (ed.), The Cambridge companion to Galileo (Cambridge, 1998), 80-145; Romano, op. cit. (ref. 1); and Chikara Sasaki, Descartes's mathematical thought (Dordrecht, Boston and London, 2003).

6. Kessler, op. cit. (ref. 5); Romano, op. cit. (ref. 1); and Sasaki, op. cit. (ref. 5).

7. Romano, op. cit. (ref. 1), 135, n. 8. Romano also names the example of Federico Commandino's preface to his Euclid edition of 1572.

8. Richard Sorabji (ed.), Aristotle transformed: The ancient commentators and their influence (New York, 1990), 25.

9. Brian Copenhaver and Charles Schmitt (eds), Renaissance philosophy (Oxford and New York, 1992), 69.

10. See Mario Otto Helbing, "La fortune des commentaires de Proclus sur le premier livre des Eléments d'Euclide à l'époque de Galilée", in Gerald Bechtle and Dominic O'Meara (eds), La philosophie des mathématiques de l'Antiquité tardive (Fribourg, 2000), 173-93, pp. 175-180.

11. Alessandro Piccolomini, De certitudine mathematicarum (Rome, 1547), f. 69v: “... eousque comprimendam [sententiam meam] duxi, donec Proclum ipsum, hoc idem sentire cognoscens, maxima animi laetitia affectus, testem tam locupletem nactus, id ipsum dehinc clara voce frequenter asserui." / "I chose to withhold my opinion until I found Proclus himself, learning that he feels exactly the same. With my soul filled with enormous joy, for having found such a rich witness, I have declared it loudly since then."

12. For example, Giuseppe Biancani, De natura mathematicarum (Bologna, 1615): "Sequatur tertio loco Procli ipsius auctoritas...." / "Thirdly, let the authority of Proclus himself follow...."

13. Piccolomini, op. cit. (ref. 11), f. 105r: "Plures etiam possem afferre rationes concludentes demonstrationes mathematicas, non esse potissimas. Sed haec sufficiant, praesertim cum authoritates habeamus mirabiles. Et primo Proclum virum illustrem in mathematicis." / "I could bring forward even more reasons that conclude that mathematical demonstrations are not potissimae. But these will be sufficient, especially because we have wonderful authorities. And 
first of all Proclus, an illustrious man in the field of mathematics."

14. See Neal Gilbert, Renaissance concepts of method (New York and London, 1960), 30-36, and Copenhaver and Schmitt, op. cit. (ref. 9), 69.

15. Paul Lawrence Rose, The Italian renaissance of mathematics: Studies on humanists and mathematicians from Petrarch to Galileo (Geneva, 1975), 286; Anna De Pace, Le matematiche e il mondo: Ricerche su un dibattito in Italia nella seconda metà del Cinquecento (Milan, 1993), 11; and Sasaki, op. cit. (ref. 5), 42.

16. For the reoccurrence of the theme of concordance between Plato and Aristotle during the Renaissance, see De Pace, op. cit. (ref. 15), 263.

17. This is especially the case in the great success of the so-called mixed sciences, which applied mathematics to the study of nature. The recovery and spread of texts from Archimedes, Hero, and Pappus in mechanics, Euclid, Archimedes, and Appolonius in geometry, Ptolemy and Theodosius in astronomy, and so on, put the mathematicians of the Renaissance in possession of techniques far more sophisticated than those available in the Middle Ages, see Rose, op. cit. (ref. 15), 2.

18. Piccolomini, op. cit. (ref. 11 ), f. 69r: "Mathematicas demonstrationes, in primo esse ordine certitudinis ... testatur Averroes 2. Metaph. com. 16. super illis verbis Aristotelis.... Quam quidem Averrois authoritatem, omnes fere latini, quos ego viderim, veluti ex antiquioribus, Divus Albertus, Divus Thomas, Marsilius, et Egidius; ex recenterioribus vero, Zimarra, Suessanus, Acciaiolus, et plerique alii ... ita interpretati sunt." / "Mathematical demonstrations are in the first order of certainty ... so Averroës attests on Aristotle's words in 2. Metaph. com. 16.... Indeed, nearly all Latin [commentators], from the ancient ones St Albertus, St Thomas, Marsilius and Egidius; from the recent ones Zimarra, Suessanus, Acciaiolus and many more ... have interpreted that authority of Averroës as such."

19. For a more extensive treatment of this technical matter, see Nicholas Jardine, "Epistemology of the sciences", in Charles Schmitt and Quentin Skinner (eds), The Cambridge history of Renaissance philosophy (Cambridge, 1988), 685-712, p. 687.

20. Mathematical demonstrations do not always provide the true and only cause, since there may be different mathematical demonstrations of the same property, as Piccolomini displays with examples from Euclid, see Piccolomini, op. cit. (ref. 11), ff. 100r-105v. For a more detailed view on Piccolomini's technical arguments, see Paolo Mancosu, Philosophy of mathematics and mathematical practice in the seventeenth century (New York and Oxford, 1996), 12, and Jardine, op. cit. (ref. 19), 693-4.

21. Piccolomini, op. cit. (ref. 11), f. 95r: "Concludit ergo Proclus ex Platone, quod res ipsae mathematicae, de quibus fiunt demonstrationes, nec omnino in subiecto sensibiles sunt, nec penitus ab ipso liberatae, sed in phantasia ipsa reperiuntur figurae illae mathematicae, habita tamen occasione a quantitatibus in materia sensibili repertis.... Materia ergo harum scientiarum, erit quantum ipsum, hoc modo, ut ita dicam, phantasiatum...."

22. Piccolomini refers to quantitas as "omnium sensatissimorum sensatissimum", ibid., f. 106v.

23. Feldhay, op. cit. (ref. 5), 83-84.

24. Maarten Van Dyck, An archaeology of Galileo's science of motion (Gent, 2006), 45.

25. Piccolomini, op. cit. (ref. 11), f. 97r: "cum non detur inter quanta naturalia, quod trinam dimensionem non recipiat, nec vera aequalitas, nec tandem quaevis figura, circularis, triangularis, aut quaevis alia, exacta penitus \& absoluta." / "since among natural quantities nothing occurs that does not receive three dimensions, nor true equality is found, nor any figure, circular, triangular, or whatever, that is truly exact and absolute."

26. Van Dyck, op. cit. (ref. 24), 46.

27. De Pace, op. cit. (ref. 15), 71.

28. For a comprehensive account of imagination and mathematics in Proclus, see Dmitri Nikulin, 
"Imagination and mathematics in Proclus", Ancient philosophy, xxviii (2008), 153-72.

29. Proclus, In primum Euclidis elementorum librum commentarii, p. 1 [I follow the pagination of Friedlein's edition (Leipzig, 1873)].

30. Proclus. A commentary on the first book of Euclid's Elements, translated, with introduction and notes, by Glenn R. Morrow and with a new foreword by Ian Mueller (Princeton, 1992), p. xviii.

31. Proclus, op. cit. (ref. 29), 18.

32. Ibid., 12-18 and 48-57.

33. Ibid., 12.

34. See Morrow (trans1.), op. cit. (ref. 30), 12-13.

35. Proclus, op. cit. (ref. 29), 12-13.

36. Ibid., 13-14.

37. Ibid., 14-15.

38. Mueller, op. cit. (ref. 30), p. xxvi.

39. De Pace, op. cit. (ref. 15), 65.

40. See Ian Mueller, “Aristotle's doctrine of abstraction in the commentators”, in Sorabji (ed.), op. cit. (ref. 8), 463-80.

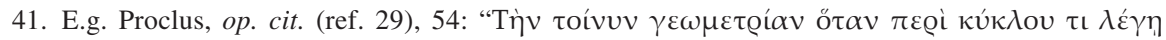

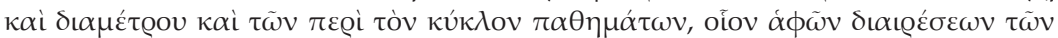

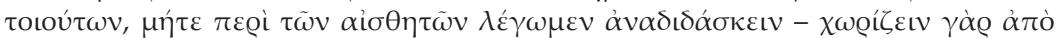

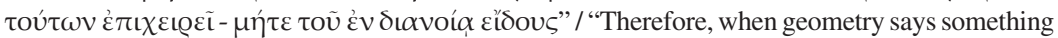
about the circle or its diameter and about its accidental properties, such as tangents, segments and the like, let us not say that it is instructing us about sensible things for it attempts to separate from them - nor about the Form in the understanding."

42. De Pace, op. cit. (ref. 15), 64.

43. Procli Diadochi Lycii in primum Euclidis Elementorum commentariorum libri iv, transl. by Francesco Barozzi (Padua, 1560).

44. Van Dyck, op. cit. (ref. 24), 47.

45. See, for example, Francesco Barozzi, Lectiones in Procli commentarios, 22, ed. by De Pace as an appendix: De Pace, op. cit. (ref. 15), 339-430: "Naturales autem probabiles atque debilissimae sunt, tum propter instabilitatem sensibilis materiae, tum quoniam ab opinione et sensu diiudicantur, qui facile decipi fallique potest." / "Natural [objects] are probable and feeble, both due to the instability of sensible matter and to the fact that they are judged by opinion and the senses, which can easily be misled and deceived."

46. For example, the first chapter of the Prolegomena seems to be an explicit refutation of the arguments given by Pereira, see Feldhay, op. cit. (ref. 5), 94.

47. E.g. Kessler, op. cit. (ref. 5); Romano, op. cit. (ref. 1), 158; and Sasaki, op. cit. (ref. 5), 55. The exception here is Peter Dear, to whom we shall return.

48. Clavius, op. cit. (ref. 3), i, 3: "Quam quidem divisionem ... ferme ad verbum ex Proclo iuxta interpretationem Francisci Barocii Patricii Veneti excerptam his subiicere statui." / "I chose to annex this division almost literally from Proclus, hereby following the transcribed interpretation of Francesco Barozzi, Venetian nobleman." See also Romano, op. cit. (ref. 1), 158, and Sasaki, op. cit. (ref. 5), 50-51. For Clavius's knowledge of the Greek editio princeps, see Kessler, op. cit. (ref. 5), 295ff.

49. For Clavius's acknowledgement of Proclus's authority, compare: Clavius, op. cit. (ref. 3), i, 126: "qui enim negat maiorem esse auctoritatem, meliora argumenta Procli quam Peletarii?" / "After all, who denies that Proclus's authority is greater, that Proclus's arguments are better than those of Peletarius?" Here Clavius appeals to Proclus in the technical discussion concerning the angulus contactus; see ref. 10. 
50. Clavius, op. cit. (ref. 3), i, 5: "Quoniam disciplinae mathematicae de rebus agunt, quae absque ulla materia sensibili considerantur, quamvis reipsa materiae sint immersae, perspicuum est eas medium inter metaphysicum, \& naturalem scientiam obtinere locum, si subiectum earum consideremus, ut recte a Proclo probatur, metaphysices etenim subiectum ab omni est materia seiunctum, \& re, \& ratione: physices vero subiectum \& re, \& ratione materiae sensibili est coniunctum: unde cum subiectum mathematicarum disciplinarum extra omnem materiam consideretur, quamvis re ipsa in ea reperiatur, liquido constat hoc medium esse inter alia duo. Si vero nobilitas atque praestantia scientiae ex certitudine demonstrationum, quibus utitur, sit iudicanda: haud dubie mathematicae disciplinae inter caeteras omnes principem habebunt locum."

51. Dear, op. cit. (ref. 5), 37.

52. Ibid., 36-37; Feldhay, op. cit. (ref. 5), 94; and Smolarski, op. cit. (ref. 1).

53. Clavius, op. cit. (ref. 3), i, 5: "ab Aristotele, veluti rami ex trunco aliquo, exortae, adeo \& inter se, \& nonnumquam a fonte ipso Aristotle diffident." / "From Aristotle, like branches from a trunk, they originate, and to such a degree they disagree with each other and sometimes with Aristotle, the source himself." This argument is repeated more extensively in Clavius's In Sphaeram Ioannis de Sacro Bosco Commentarius of 1570 (Clavius, op. cit. (ref. 3), iii, 4) and is also found in Justus Velsius's Oratio de mathematicarum disciplinarum vario usu dignitateque (Leuven, 1544); see Steven Vanden Broecke, "Humanism, philosophy and the teaching of Euclid at a northern university: The Oration on the various uses and dignities of the mathematical disciplines, 1544, of Justus Velsius", Lias, xxv (1998), 43-68, pp. 54-55.

54. Clavius, op. cit. (ref. 3), i, 5: "Neque enim ad metaphysicam, ut eleganter ostendit Proclus, ulli patet aditus, nisi per mathematicas disciplinas.... Non parum etiam conducunt hae artes ad philosophiam naturalem, moralem, dialecticam, \& ad reliquas id genus doctrinas ... ut perspicue docet Proclus." / "There is not any entrance open to metaphysics, as Proclus elegantly shows, but through the mathematical disciplines... These arts also contribute to natural, moral, dialectical philosophy, and other doctrines of that sort ... as Proclus clearly demonstrates."

55. Sasaki, op. cit. (ref. 5), 56.

56. Francesco Barozzi, Opusculum, in quo una oratio, et duae quaestiones: altera de certitudine, et altera de medietate mathematicarum, continentur (Padua, 1560), f. 40 r, quoted in Sasaki, op. cit. (ref. 5), 56: "Naturalem esse primam ordine, quoad nos, Mathematicam secundam, Divinam tertiam: ordine vero naturae divinam esse primam, secundam mathematicam, postremam naturalem, ita ut Mathematica re vera media semper sit inter naturalem, \& divinam...."

57. Ammonius, In quinque Porphirii Voces Commentarii, f. 6r. See De Pace, op. cit. (ref. 15), 132-3.

58. Barozzi, op. cit. (ref. 56), f. 38r, quoted in De Pace, op. cit. (ref. 15), 129-30: "Plato et Aristoteles discrepare videntur. Plato enim eiusque sectatores mathematicam naturali praeposuere. Aristoteles autem omnesque peripatetici naturalem mathematica priorem esse dixerunt." / "Plato and Aristotle seem to disagree. After all, Plato and his followers preferred mathematics to natural philosophy. Yet Aristotle and all the Peripatetics said that natural philosophy is prior to mathematics."

59. Sasaki, op. cit. (ref. 5), 56. For the relation between Barozzi and Clavius, see also Romano, op. cit. (ref. 1), 158.

60. Francesco Barozzi, Oratio ad philosophiam virtutemque ipsam adhortatoria, habita Patavii in Academia Potentium die 25 Novembri 1557 (Padua, 1558).

61. Ibid., ff. 9r-9v: "Alia immersa penitus in materia sunt, ita ut ab ea nec secundum esse, neque secundum rationem separari possint, quae naturalia appellantur. Alia autem a materia, et secundum esse, et secundum rationem formalem seiuncta sunt, quae divina esse dicuntur. Alia vero, quae secundum rationem formalem quidem separari, secundum vero esse haud separari a materia sensibili possunt, quae Mathematica nuncupantur."

62. Barozzi, op. cit. (ref. 45), 15: "verum animadvertum est quod, dum in materia sensibili haec [sc. the mathematical objects] consistunt, res naturales esse dicuntur; cum autem ab omni materia 
sensibili separata[e] fuerint, tunc mathematicae essentiae vere appellantur, quae quidem nullibi nisi in phantasia et in anima nostra subsistunt."

63. De Pace, op. cit. (ref. 15), 137.

64. Barozzi, op. cit. (ref. 45), 11: "alia autem (ut Proclus noster passim asseverat, utque in sequentibus melius nobis perspicuum erit) cum secundum esse, tum secundum rationem formalem a materia sensibili separata sunt in intelligibilique materia subsistunt, quae quidem mathematica dicuntur et a mathematica contemplatricis philosophiae parte considerantur." Compare also with Barozzi, op. cit. (ref. 56), f. 37v: "quae autem mathematica esse dicuntur, et a materia sensibili quidem omino separata, intelligibili autem inseparabilia sunt, medium inter haec locum sibi vendicarunt." I "Those which are called mathematical objects, and are indeed fully separated from sensible matter, but are inseparable from intelligible [matter], have claimed the place intermediate between them" (my emphasis).

65. De Pace, op. cit. (ref. 15), 138.

66. Cf. Barozzi, Lettera di F. Barozzi ad Alvise Buonrizzo, f. 13r, quoted in De Pace, op. cit. (ref. 15): "non vol stare sopra la scorza delle parole, ma penetrar piu dentro alla midolla della cosa, ritrovera, che tutti duo questi filosofi sono stati d'accordo ma differenti solamente in parole."

67. "Unde cum subiectum mathematicarum disciplinarum extra omnem materiam consideretur, quamvis re ipsa in ea reperiatur ..." should be translated as "then, as the subject of the mathematical disciplines is considered free from all matter, although in reality it [sc. the subject] is found in it [sc. matter]", this in contradistinction to the translation "although it [i.e. matter] is found in the thing itself" (Rivka Feldhay, Galileo and the Church: Political inquisition or critical dialogue? (Cambridge, 1995), 217), "even though it [matter] is found in the thing itself" (Feldhay, op. cit. (ref. 5), 96), "although it [i.e., matter] is found in the thing itself" (Dear, op. cit. (ref. 5), 37), and "although matter is really found in it" (Sasaki, op. cit. (ref. 5), 56).

68. Feldhay, op. cit. (ref. 67), 216. For the 'abstract' character of mathematical objects, see: Clavius, op. cit. (ref. 3), i, 5: "Quam ob rem, antequam a rebus physicis, quae materiae sensibus obnoxiae sunt coniunctae, ad res metaphysicas, quae sunt ab eadem maxime avulsae, intellectus ascendat, necesse est, ne harum claritate offundatur, prius eum assuefieri rebus minus abstractis, quales a mathematicis considerantur, ut facilius illas possit comprehendere." / "Therefore, before the intellect ascends from physical objects, which are joined to that matter subject to the senses, to metaphysical entities, which are the most torn away from it [sc. sensible matter], it is necessary, in order that it would not be damaged by the latter's clarity, that it first grows familiar with things that are less abstract, which are considered by mathematics, so it is able to better understand them [sc. metaphysical objects]" (my emphasis).

69. Aristotle, Metaphysics, E, I, 1025b26-1026a16.

70. Dear, op. cit. (ref. 5), 37.

71. Iamblichus, Syrianus, and Proclus put forward the projectionist point of view, see Mueller, op. cit. (ref. 40).

72. Alexander of Aphrodisias's interpretation seems to oscillate between a constructive abstractionistreading and a view at first glance similar to Clavius's. See Elisabetta Cattanei, "Gli enti matematici 'per astrazione' secondo Alessandro di Afrodisia e lo Pseudo-Alessandro", in Giancarlo Movia (ed.), Alessandro di Afrodisia e la "Metafisica" di Aristotele (Milan, 2003), 255-76, pp. 260-72. Nevertheless, I did not find any evidence of Clavius's having been acquainted first hand with Alexander's interpretation.

73. Mueller, op. cit. (ref. 40), 480. See also Cattanei, op. cit. (ref. 72), for a critical reading of Mueller's rather rigid division.

74. Benedictus Pereira, De communibus omnium rerum naturalium principiis (Rome, 1576), ff. 374-5.

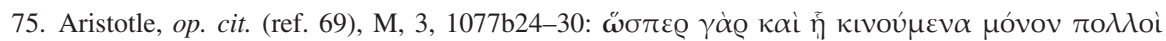

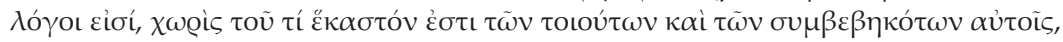




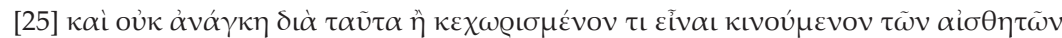

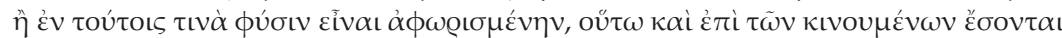

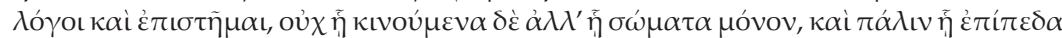

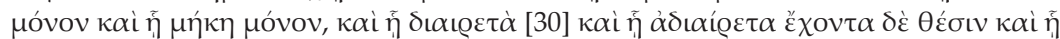

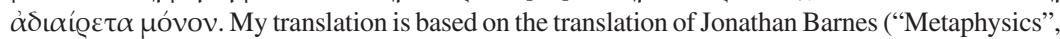
in Jonathan Barnes (ed.), The Cambridge companion to Aristotle (Cambridge, 1995), 66-108, p. 85), with some modifications.

76. Jonathan Lear, "Aristotle's philosophy of mathematics", The philosophical review, xci (1982), 161-92, pp. 168-9.

77. Aristotle, op. cit. (ref. 69), M, 3, 1077b18-1078a31.

78. Barnes, op. cit. (ref. 75), 85 .

79. Ibid., 86.

80. Edward Hussey, "Aristotle on mathematical objects", in Ian Mueller (ed.), ПEPI T $\Omega N$ $M A \Theta H M A T \Omega N$ (Edmonton, 1991), 105-34, p. 116.

81. From this perspective, one could consider Barozzi's "derivative being" as "a being assumed as a helpful fiction".

82. Aristotle, op. cit. (ref. 69), M, 3, 1078a28.

83. Lear, op. cit. (ref. 76), 175.

84. Aristotle, Physics, B, 2, $193 \mathrm{~b} 23$.

85. Clavius, op. cit. (ref. 3), i, 5: "rebus minus abstractis, quales a mathematicis considerantur." / "less abstract entities which are considered by mathematics."

86. Clavius, op. cit. (ref. 3), i, 5: "Cum igitur disciplinae mathematicae veritatem adeo expectant, adamant, excolantque, ut non solum nihil, quod sit falsum, verum etiam nihil, quod tantum probabile existat, nihil denique admittant, quod certissimis demonstrationibus non confirment, corroborentque, dubium esse non potest, quin eis primus locus inter alias scientias omnes sit concedendus."

87. See Ian Mueller, "Aristotle on geometrical objects", in Jonathan Barnes, Malcolm Schofield and Richard Sorabji (eds), Articles on Aristotle. 3: Metaphysics (London, 1979), 96-107; Lear, op. cit. (ref. 76); Mueller, op. cit. (ref. 40); Hussey, op. cit. (ref. 80); Barnes, op. cit. (ref. 75); and John Cleary, Aristotle and mathematics: Aporetic method in cosmology and metaphysics (Leiden, New York and Cologne, 1995).

88. Feldhay, op. cit. (ref. 5), 97.

89. See, for example, Clavius, op. cit. (ref. 3), i, 5-6, the chapter "Various uses of the mathematical disciplines".

90. See Mario Biagioli, "The social status of Italian mathematicians, 1450-1600", History of science, xxvii (1989), 41-95, p. 54. 